\title{
Rhetoric of Commercial Film and the Response of Viewers
}

\author{
Yoji Kawamura \\ Faculty of Business Administration, Kindai University \\ 3-4-1 Kowakae, Higashi-osaka, Osaka 577-8502, Japan \\ E-mail: kawamura@bus.kindai.ac.jp
}

\begin{abstract}
This study first outlines a view of the rhetoric of commercial films as a combination of commercial film techniques. Next, it discusses the relationship between the rhetoric of commercial films and perception/positive factors based on a variety of surveys. It then shows the structure of the relationship between the rhetoric of commercial films and perception/positive factors based on the discussion. Finally, it summarizes the rhetorical patterns in advertisement based on the structure thus identified. This study showed that there is a correlation between the overall rhetorical type and perception/positive factors by introducing the framework of "overall rhetorical types" as a combination of commercial film techniques. Interestingly, the overall rhetorical type, which is an approach to classify commercial films based on commercial film techniques, is found to correlate with the viewer's perception and positive factors. On the basis of the structure identified in the study, expressive characteristics of commercial films can be summarized as 4 expressive characteristics.
\end{abstract}

Keywords: commercial film, rhetoric, overall rhetorical type, perception, positive factor

\section{Introduction}

This study first outlines a view of the rhetoric of commercial films as a combination of commercial film techniques. Next, it discusses the relationship between the rhetoric of commercial films and perception/positive factors based on a variety of surveys. It then shows the structure of the relationship between the rhetoric of commercial films and perception/positive factors based on the discussion. Finally, it summarizes the rhetorical patterns in advertisement based on the structure thus identified.

\section{Views on Commercial Film Techniques and Rhetoric}

Commercial film techniques contained in commercial films are complex with a variety of representation elements, but viewers do not form their perception of the films by comprehending all these techniques or representation elements. In particular, in the case of commercial films with time constraint (between 15 and 30 seconds), it is speculated that viewers use their intuition to capture physiological elements, which cannot be verbalized and form their perception, by focusing on the differences from their own reality.

Commercial films are visual representations that bring certain disturbance to the physical reality in which consumers consume products in the real world. Commercial film techniques and rhetoric are classified in reference to the disturbance (certain manipulation: addition or deletion). In this study, to grasp commercial film techniques and rhetoric systematically, they are defined as "rules that add some manipulation (addition or deletion) to the basic advertising story, mise-en-scène, editing and sound effects." Here, "the basic advertising story, mise-en-scène, editing and sound effects" refer to the general consumer's behavior of consuming products in the real world. Advertising story technique expresses "the product function (the product itself or its performance)" and "product reception (the scene in 
which the consumer receives the product)." Mise-enscène technique refers to "the real space;" "one consumer;" "the protagonist is not a celebrity with a strong character;" "the protagonist or the product is not in fast movement or in slow motion;" and "the fixed camera shot." Editing technique refers to "a slow tempo (a large number of average number of seconds per shot);" "continuation (movements are usually connected);" and "temporal series (there is no manipulation to chronology)." Sound effect technique refers to "silent (slow tempo music or no music)."

Moreover, advertising story techniques are classified into two categories: "representation of reception (a representation of the scene in which the consumer receives the product)" and "deletion of reception (the scene in which the consumer receives the project is not represented)." Mise-en-scène techniques are classified into two categories: "dynamic (the protagonist or product moves fast, slow or circles; or the camera shot is not fixed)" and "stable (the protagonist or product does not move fast or is not in slow motion; the camera shot is fixed)." Editing techniques are classified into two categories: "dynamic (fast tempo or discontinues movements)" and "stable (slow tempo or no tempo)." Sound effect techniques are classified into two categories: "dynamic (fast tempo)" and "stable (slow tempo or no tempo)." These categories are referred to as technique types. The combination of the technique types constitutes the overall rhetorical types. The number of combination is $16(2 \times 2 \times 2 \times 2)$.

Kawamura analyzed the overall rhetorical types of 100 commercial films. $1 \mathrm{~A}$ and $1 \mathrm{~B}$, which are "dynamic" in terms of mise-en-scène, sound effect, and editing techniques, are most frequent and account for $46 \%$ of the total films (Fig. 1).

\section{Relationship between the Rhetoric of Commercial Films and Perception}

Viewers' response is defined as perception and positive factors, and the relationship between the rhetoric of commercial films and perception/positive factors is outlined based on a number of surveys.

\subsection{Rhetoric of Commercial Film and Perception}

Kawamura analyzed the correlation between the rhetoric of commercial films and perception with 16 films of beer and 22 films of personal computers. ${ }^{2}$ The relationship (correlation) between the overall rhetorical type (from 1A to 8B) and perception shows that there is a certain structure between the two as seen in $1 \mathrm{~A}$ being related to "looks delicious," "fresh," and "looks cool," 1B to "rhythmical," "po werful," and "looks cool;" 2B to "creative" and "vivid;" $3 \mathrm{~A}$ to "feels clean" and "fashionable," 7A to "rich nature," "feels cool," and "idyllic," and 8B to "somehow sad," "simple," and "non-organic." It is shown that out of 106 image words extracted from the data, $80(76 \%)$ correlate with the overall rhetorical type.

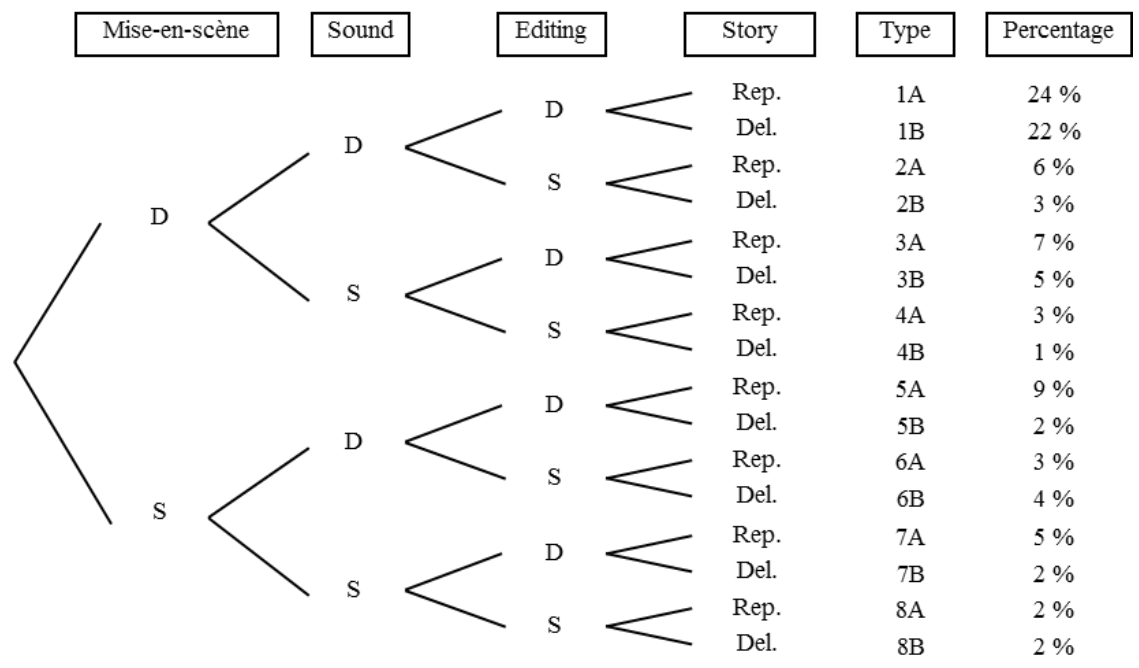

D: Dynamic, S: Stable, Rep.: Representation of reception, Del.: Deletion of reception

Fig. 1. System and percentage of overall rhetorical types. ${ }^{1}$ 


\subsection{Rhetoric of Commercial Films and Positive Factors}

Kawamura analyzed the correlation between the rhetoric of commercial films and perception/positive factors with 100 commercial films that were ranked among top ten for the new film category in each month (20042005) published by CM Research Institute. ${ }^{1,3}$ The analysis showed that there is a structure between the overall rhetorical type (from $1 \mathrm{~A}$ to $8 \mathrm{~B}$ ) and positive factors as seen in $1 \mathrm{~A}$ being related to "because it is sexy;" 1B to "the firm's attitudes appear to be sincere;"
$3 \mathrm{~A}$ to "it is humorous" and "a good story;" $3 \mathrm{~B}$ to "cute," $5 \mathrm{~A}$ to "attracted by the product;" $6 \mathrm{~B}$ to "not fashionable but likeable;" 7A to "reassuring," 7B to "it is pleasantly persuasive," $8 \mathrm{~A}$ to "it is pleasantly persuasive" and "it feels at the cutting-edge of time;" and 8B to "impressive catch phrases" and "good visual images/videos." It is shown that out of 77 image words extracted from the data, $59(77 \%)$ are correlated with the overall rhetorical types, and out of 15 positive factors, $13(87 \%)$ are correlated with the overall rhetorical type.

Table 1. Relationship between the rhetoric of commercial films and perception/positive factors.

\begin{tabular}{|c|c|c|c|c|c|c|c|}
\hline \multicolumn{4}{|c|}{ Rhetorical Type } & \multirow[b]{2}{*}{ Perception $^{2}$} & \multirow[b]{2}{*}{ Perception $^{1}$} & \multirow[b]{2}{*}{ Positive Factors ${ }^{1}$} & \multirow[b]{2}{*}{ Effect Type } \\
\hline Type & $\begin{array}{c}\text { Mise- } \\
\text { en-scène }\end{array}$ & $\begin{array}{c}\text { Sou } \\
\text { nd }\end{array}$ & $\begin{array}{l}\text { Edit } \\
\text { ing }\end{array}$ & & & & \\
\hline $1 \mathrm{~A} / \mathrm{B}$ & $\mathrm{D}$ & $\mathrm{D}$ & D & $\begin{array}{l}\text { looks delicious, fresh, } \\
\text { looks cool, dazzling, cold, } \\
\text { pleasant, lively, congenial, } \\
\text { impatient, desperate, sporty, } \\
\text { haste, fighting, speedy, } \\
\text { light, conspicuous, tense, } \\
\text { surprised, rhythmical, } \\
\text { thrilling, powerful, fast, } \\
\text { futuristic, speed, } \\
\text { contemporary }\end{array}$ & $\begin{array}{l}\text { speedy, realistic, } \\
\text { eerie, surprise }\end{array}$ & $\begin{array}{l}\text { "because it is } \\
\text { sexy" } \\
\text { "the firm's } \\
\text { attitudes appear to } \\
\text { be sincere" }\end{array}$ & thrilling \\
\hline $2 \mathrm{~A} / \mathrm{B}$ & $\mathrm{D}$ & $\mathrm{D}$ & $\mathrm{S}$ & creative, vivid & $\begin{array}{l}\text { fierce, energetic, light, } \\
\text { gorgeous, colorful }\end{array}$ & & light, vivid \\
\hline $3 \mathrm{~A} / \mathrm{B}$ & $\mathrm{D}$ & $\mathrm{S}$ & D & $\begin{array}{l}\text { speed, stylish, feels clean, } \\
\text { fashionable, elegance, } \\
\text { simple, refresh }\end{array}$ & $\begin{array}{c}\text { serious, healing, } \\
\text { funny, happy, } \\
\text { peaceful, sad, pitiful, } \\
\text { puzzled, miserable }\end{array}$ & $\begin{array}{l}\text { "it is humorous" } \\
\text { "a good story" } \\
\text { "cute" }\end{array}$ & $\begin{array}{l}\text { tempo, } \\
\text { enjoyable }\end{array}$ \\
\hline $5 \mathrm{~A} / \mathrm{B}$ & $\mathrm{S}$ & $\mathrm{D}$ & D & & $\begin{array}{l}\text { impact, cool, gentle, } \\
\text { magnificent }\end{array}$ & $\begin{array}{l}\text { "attracted by the } \\
\text { product" }\end{array}$ & magnificent \\
\hline $4 \mathrm{~A} / \mathrm{B}$ & $\mathrm{D}$ & $\mathrm{S}$ & $\mathrm{S}$ & $\begin{array}{l}\text { simple, heartwarming, } \\
\text { daily, couple, refresh, relax, } \\
\text { tranquil, my pace, fierce, } \\
\text { slow, design, transparent, } \\
\text { white, chic, mood, change }\end{array}$ & fashionable & & daily \\
\hline $6 \mathrm{~A} / \mathrm{B}$ & $\mathrm{S}$ & $\mathrm{D}$ & $\mathrm{S}$ & tired, a comedy & $\begin{array}{l}\text { tranquil, comical, } \\
\text { enjoyable, hope }\end{array}$ & $\begin{array}{l}\text { "not fashionable } \\
\text { but likeable" }\end{array}$ & $\begin{array}{c}\text { heartwarming, } \\
\text { enjoyable }\end{array}$ \\
\hline $7 \mathrm{~A} / \mathrm{B}$ & $\mathrm{S}$ & S & $\mathrm{D}$ & $\begin{array}{l}\text { rich nature, feels cool, } \\
\text { idyllic, running feeling, idle } \\
\text { feeling, wonder, } \\
\text { expectation, doubt, anxiety, } \\
\text { indoor, lifestyle feeling }\end{array}$ & $\begin{array}{l}\text { elegance, natural, rich } \\
\text { knowledge, wonder }\end{array}$ & $\begin{array}{l}\text { "reassuring" } \\
\text { "it is pleasantly } \\
\text { persuasive" }\end{array}$ & $\begin{array}{l}\text { nature, } \\
\text { reassuring }\end{array}$ \\
\hline $8 \mathrm{~A} / \mathrm{B}$ & S & $\mathrm{S}$ & $\mathrm{S}$ & $\begin{array}{c}\text { quiet, domestic, pure, } \\
\text { warm, somehow sad, drift, } \\
\text { simple, non-organic, calm, } \\
\text { home, stinking, relaxing, } \\
\text { magnificent, Japan, chic, } \\
\text { dark }\end{array}$ & $\begin{array}{l}\text { relaxing, calm, } \\
\text { gorgeous, } \\
\text { heartwarming, fresh, } \\
\text { dim, hard, powerful }\end{array}$ & $\begin{array}{c}\text { "it is pleasantly } \\
\text { persuasive" } \\
\text { "it feels at the } \\
\text { cutting-edge of } \\
\text { time" } \\
\text { "impressive catch } \\
\text { phrases" } \\
\text { "good visual } \\
\text { images/videos" }\end{array}$ & rest, aesthetic \\
\hline
\end{tabular}




\section{Structure of the Rhetoric of Commercial Films and Perception/Positive Factors}

Table 1 shows the relationship between the rhetoric of commercial films and perception/positive factors as examined in 3.1 and 3.2. Kawamura ${ }^{2}$ analyzed commercial films of beer (16 films) and personal computers (22 films); Kawamura ${ }^{1}$ analyzed commercial films according to product types other than beer and personal computers. (Of the 100 films analyzed, three are films of beer, one of personal computers, and 96 of other products.) The tale shows that there is a close relationship (structure) between the overall rhetorical type and perception regardless of product category (Fig. 2).

\section{Rhetorical Patterns in Commercial Films}

As viewers use diverse knowledge and knowledge processing when perceiving commercial films, it is difficult to structure or verbalize the viewer's perceptions. Consequently, it is not easy to achieve perception that is loyal to the image that the advertiser wants to convey. However, the study showed that there is a correlation between the overall rhetorical type and perception/positive factors by introducing the framework of "overall rhetorical types" as a combination of commercial film techniques. Interestingly, the overall rhetorical type, which is an approach to classify commercial films based on commercial film techniques, is found to correlate with the viewer's perception and positive factors.

On the basis of the structure identified in the study, expressive characteristics of commercial films can be summarized as follows:

1. Overall rhetorical type 1 ("dynamic" mise-en-scène, sound effects and editing) overwhelms the viewer and leaves a strong impression of the actors and the company.

2. Overall rhetorical types 2,3 , or 5 (one of mise-enscène, sound effects, and editing is set as "stable") attracts the viewer's attention and interest to the actor's movement, the story, or the product.

3. Overall rhetorical types 4, 6, or 7 (two of mise-enscène, sound effects, and editing are set as "stable") encourages the viewer to relate to/sympathize with the advertisement content or representation.

4. Overall rhetorical type 8 ("stable" mise-en-scène, sound effects, and editing) encourages the viewer to evaluate the advertisement concept and representation aesthetically.

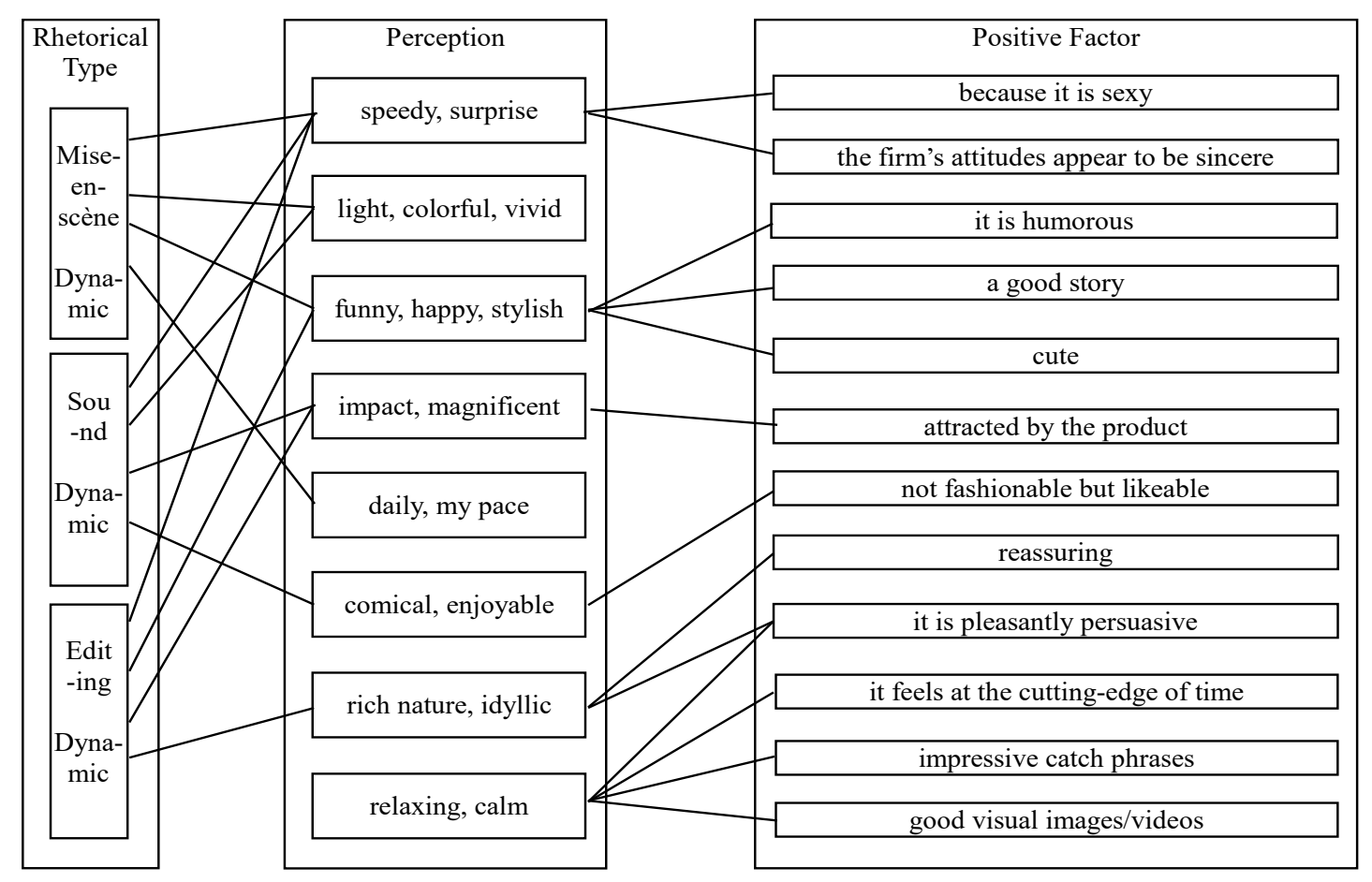

Fig. 2. Structure of the overall rhetorical type and perception/positive factors. 


\section{Strategic Rules of Advertising Communication}

Kawamura have ruled advertisement communication strategy corresponding to the interest level of people for products. $^{4}$ From the rules of Kawamura ${ }^{4}$ and this research, it is conceivable to set the following strategic or tactical rules of advertising communications. These rules are applicable to the intelligent robot that has know-how of advertising communication between robot and human being.

1. For the unfamiliar people for products, the robot stimulates the people's interest by presenting the wonder or extraordinary scene and information (for example, the environment or scene that the products are hidden consciously, the scene where there has been a lot of people etc.). Overall rhetorical type $1,2,3$, or 5 is effective.

2. The robot tries to grasp whether the people's interest has been evoked. If the people's interest has been aroused, the robot stimulates the willingness to buy by presenting a scene of functions, acceptance and effects of the product. Overall rhetorical type $4,6,7$, or 8 is effective.

\section{Acknowledgements}

This work was supported by JSPS KAKENHI Grant Number 22500102.

\section{References}

1. Kawamura, Y., A Study on the Technique-rhetorics and Effects of Commercial Film, Cognitive Studies, 14(3) (2007), pp.409-423. (In Japanese)

2. Kawamura, Y., An Analysis on Rhetoric of the Commercial Film of Beer and Personal Computer - A Symbolic Approach on Rhetoric of Commercial Film, Journal of Advertising Science, 47 (2006), pp.33-48. (In Japanese)

3. CM Research Institute, Monthly Top $10 \mathrm{CM}$ of New Works, CM INDEX, 19(4)-20(6) (2004-2005). (In Japanese)

4. Kawamura, Y., A Viewing Experiment on the Effects of Advertising Story, Journal of Robotics, Networking and Artificial Life, 3(2) (2016), pp.92-95. 